\title{
Shell's influence on drying kinetics, color and volumetric shrinkage of Castanea sativa Mill. fruits
}

\author{
T. Delgado a,b J.A. Pereira a , P. Baptista a , S. Casal ${ }^{\text {b,* }}$, E. Ramalhosa ${ }^{\text {a, } * *}$ \\ a Mountain Research Centre (CIMO), School of Agriculture, Polytechnic Institute of Bragança, Campus de Sta. Apolónia, Apartado 1172, 5301-855 Bragança, Portugal

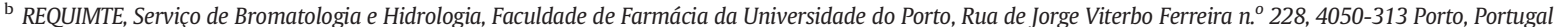

\section{A R T I C L E I N F O}

Article history:

Received 18 September 2013

Accepted 29 November 2013

\section{Keywords:}

Chestnut fruits

Varieties' behavior

Drying

Shell's influence

Mathematical models

\begin{abstract}
A B S T R A C T
Shell's influence on the drying behavior of two European chestnut (Castanea sativa Mill.) varieties, Longal and Judia, was investigated in the present work. For this purpose, chestnuts of both varieties were dried in a hot air convection oven at $50.0 \pm 2.0^{\circ} \mathrm{C}$ and air velocity of $1.0 \pm 0.1 \mathrm{~m} / \mathrm{s}$. The fruits were dried with and without outer shell, the axial dimensions, volumetric shrinkage and color being determined. Furthermore, the drying data was complemented for the first time with microscopic analyses of the shells.

Longal and Judia drying behaviors were similar (moisture ratios less than 0.20 in 35 to $45 \mathrm{~h}$ ), despite the microscopic differences in outer shell thickness (Judia: $556 \pm 43 \mu \mathrm{m}$ and Longal: $328 \pm 66 \mu \mathrm{m}$ ) and cell format (smaller cells-Judia). After determining the suitability of several drying models, good results were obtained with the Page (Judia), and Two-term exponential and Modified Page models (Longal). Concerning fruit color, a slight decrease in fruit brightness and an increase on fruit yellowness were detected along drying for both varieties. Small volumetric shrinkage was observed (10-24\%). From these results, both varieties seemed to be adequate to be used industrially to produce dried chestnut based products, showing similar drying behaviors. Regarding the influence of the outer shell on the drying process, it had a small impact on water removal. So, chestnuts can be dried with the outer shell, leading to a less expensive and non-time-consuming process because it is not necessary to peel the fruits before drying.
\end{abstract}

(C) 2013 Elsevier Ltd. All rights reserved.

\section{Introduction}

The chestnut fruit market is increasing worldwide, following the emergence of new chestnut based products, such as, chestnut flour, marron glacé, purees, and pre-cooked frozen products, among others (Pinnavaia, Pizzirani, \& Papotto, 1995). Two main chestnut species are usually commercialized: Castanea mollissima Blume and the typical European chestnut fruit, Castanea sativa Mill., including several varieties around the globe. Portugal produces $C$. sativa, being Trás-os-Montes region, located in the northeast (NE) of Portugal, the most important production area, contributing $85 \%$ of the national production. In this region, Judia and Longal are the most marketed varieties.

Abbreviations: NE, Northeast; $W, L, t$, Axial dimensions (width, length and thickness, respectively $(\mathrm{mm})) ; G R$, Geometric radius $(\mathrm{mm}) ; A R$, Arithmetic radius $(\mathrm{mm}) ; V$, Volume $(\mathrm{mL}) ; V_{t}$, Volume at the $t$ instant $(\mathrm{mL}) ; V_{0}$, Initial volume $(\mathrm{mL}) ; \mathrm{L}^{*}, \mathrm{a}^{*}, \mathrm{~b}^{*}$, Color parameters (CIELab); $W$, Instantaneous dry basis water content ( $\mathrm{kg}$ water $/ \mathrm{kg}$ dry basis); $W_{0}$ Initial dry basis water content ( $\mathrm{kg}$ water/kg dry basis); $W_{e}$, Equilibrium dry basis water

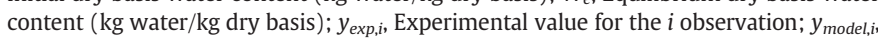
Predicted value for the $i$ observation; $n$, Number of observations; $m$, Number of parameters in each model; $D_{a p p}$, Apparent diffusivity $\left(\mathrm{m}^{2} / \mathrm{h}\right)$; SER, Sphere equivalent radius; R, Linear correlation coefficient; $M R$, Moisture ratio; a, b, c, k, n, $\mathrm{k}_{0}, \mathrm{k}_{1}, \mathrm{~g}$, h, Model parameters.

* Corresponding author. Tel.: + 351 220428638; fax: + 351226093390

** Corresponding author. Tel.: + 351 273303308; fax: + 351273325405.

E-mail addresses: sucasal@ff.up.pt (S. Casal), elsa@ipb.pt (E. Ramalhosa).
Chestnut fruits are collected in autumn, being usually sold fresh or stored under refrigeration for several months to be afterwards sold peeled and frozen. Even though good results have been reported for controlled atmospheres on quality of harvested chestnuts, the use of this technology is still uncommon (Cecchini, Contini, Massantini, Monarca, \& Moscetti, 2011). The cold storage process (the most frequent) imposes two problems: weight loss due to water evaporation and mold development (Rodrigues, Venâncio, \& Lima, 2012). Thus, it is very important to find efficient alternative preserving and transformation methods to minimize these losses, with influence on both quality of the fruit and economical revenues.

In Portugal, there is a deep tradition to store chestnuts on trays near fireplaces in order to dehydrate and preserve them for longer periods of time, this dry chestnut being named "castanha pilada". This product may also be produced industrially, using ovens or dryers, and be the raw material for chestnut flour (a gluten-free product) or later rehydrated and consumed all year. Despite being sold in local markets, in Portugal the industrial production of castanha pilada is still not common, with a clear industrial preference for frozen preservation.

Several drying methods, namely High Temperature Short Time (HTST) and Low Temperature High Velocity (LTHV), have been applied on roasting of cashew nuts (Chandrasekara \& Shahidi, 2011; Shahidi \& Chandrasekara, 2011) and as a thermal quarantine method to control moths (Tang, Ikediala, Wang, Hansen, \& Cavalieri, 2000), as well as in 
fish drying (Kilic, 2009), respectively. However, these technologies have not yet been applied to chestnuts. Nevertheless, few studies on osmotic dehydration (Moreira, Chenlo, Chaguri, \& Oliveira, 2007; Moreira, Chenlo, Torres, \& Vázquez, 2007) and on convective air-drying of European chestnut have been performed (Attanasio, Cinquanta, Albanese, \& Di Matteo, 2004; Chenlo, Moreira, \& Torres, 2007; Guiné \& Fernandes, 2006; Koyuncu, Serdar, \& Tosun, 2004; Moreira, Chenlo, Chaguri, \& Vázquez, 2005; Velić et al., 2010). When studying the effect of chestnut variety, Guiné and Fernandes (2006) and Velić et al. (2010) found some differences between them when chestnuts were dried with the outer shell (pericarp) at different temperatures. On the other hand, Moreira et al. (2005) did not find significant differences during drying of several Spanish varieties, independently of the presence of the fruit pericarp and endocarp (inner shell). In these studies, three mathematical models were successfully applied to the drying process: the Two-term, Fick's second law and Page models, respectively.

In order to get more knowledge in this topic, particularly by clarifying the influence of chestnut varieties and shells, in the present work a study on two European chestnut varieties, Longal and Judia, grown in Portugal, was developed. The suitability of several mathematical drying models was also discussed, in order to evaluate the advantage of using models with a high number of parameters. Moreover, the results were complemented for the first time with microscopic analyses of the shells. In parallel, the fruit color and volumetric shrinkage were also determined because these factors are of particular importance for a successful industrial production of hot air dried chestnuts in the near future.

\section{Material and methods}

\subsection{Plant material}

The nuts used in this study were acquired in Bragança (NE Portugal) in October 2011 and stored in cold chambers $\left(4 \pm 1{ }^{\circ} \mathrm{C}\right)$ until carrying out the drying experiments. The most representative varieties of this region, Longal and Judia, were chosen. Chestnuts were used with both shells (pericarp and endocarp) or after removing carefully the outer shell with a knife.

\subsection{Physical properties}

The three axial dimensions (width, $W$; length, $L$; and thickness, $t$ ) of all chestnuts used in the experiments were measured using a caliper. The geometric and arithmetic mean radii ( $G R$ and $A R$ ) were calculated by the following equations:

$G R=\frac{\sqrt[3]{W \times L \times t}}{2}$

$A R=\frac{(W+L+t)}{6}$

The volume of twenty chestnut fruits per variety was determined by the displacement method (Mohsenin, 1970), using glycerin as fluid, while the radius of a sphere of the same volume $(V)$ as the chestnut fruit was determined by the following equation:

Sphere equivalent radius $(S E R)=\sqrt[3]{\frac{3 V}{4 \pi}}$

This radius was compared with the $G R$ and $A R$ determined for the same fruits in order to find out relationships that allowed prediction of chestnut volume through measurement of its axial dimensions.

After determining SER, sphericity values were estimated by the following equation (Mohsenin, 1970):

Sphericity $=\frac{\text { SER }}{\text { Longest radius of the object }}$
This expression for sphericity expresses the shape character of the solid relative to that of a sphere of the same volume (Mohsenin, 1970).

In order to evaluate shrinkage during chestnut drying, the Bulk Shrinkage Coefficient was determined by the following expression (Dissa, Desmorieux, Savadogo, Segda, \& Koulidiati, 2010):

Bulk Shrinkage Coefficient $=1-\frac{V_{t}}{V_{0}}$

where $V_{0}$ is the initial volume and $V_{t}$ the volume at instant $t$. These were determined taking into account the SER estimated by the GR and $A R$ of the chestnuts.

Color analyses were carried out on chestnuts with the outer shell and inner shell, peeled and cut through the middle (interior). The color was measured with a Minolta CR-400 colorimeter in the CIELab color space, through the coordinates: $\mathrm{L}^{*}, \mathrm{a}^{*}$ and $\mathrm{b}^{*}$, using Spectra Magic Nx software (version CM-S100W 2.03.0006, Konica Minolta Company, Japan). L* is an approximate measurement of lightness, which is a property according to which each color can be considered as equivalent to a member of the gray scale, between black and white, taking values within the range of $0-100$, respectively. The $a^{*}$ coordinate takes positive values for reddish colors and negative values for greenish ones, whereas $b^{*}$ takes positive values for yellowish colors and negative values for bluish ones. For chestnuts we verified that the $b^{*}$ coordinate was more important than $a^{*}$. The instrument was always calibrated with a standard white tile before analysis. Illuminant $C$ and $2^{\circ}$ standard observer were used.

\subsection{Drying experiments}

Chestnuts with and without outer shells were dried in a forced convection oven at $50.0 \pm 2.0{ }^{\circ} \mathrm{C}$ (Fig. 1). It consisted of two fans, a heating control system (Voltage/Power Rating: $400 \mathrm{~V}(+/ 10 \%), 3$ phases/N, 50/60 Hz/approx. $7.000 \mathrm{~W}$ ), stainless steel shelves and measurement instruments, namely a temperature sensor (one Pt100 sensor DIN class A in 4-wire-circuit). The air velocity was kept constant at $1.0 \pm 0.1 \mathrm{~m} / \mathrm{s}$ throughout the experiments. The progress of the drying process was followed by weighting 80 chestnuts at regular time intervals with an accuracy of $\pm 0.001 \mathrm{~g}$, the moisture ratios $(M R)$ being determined by Eq. (6).

$M R=\frac{W-W_{e}}{W_{0}-W_{e}}$

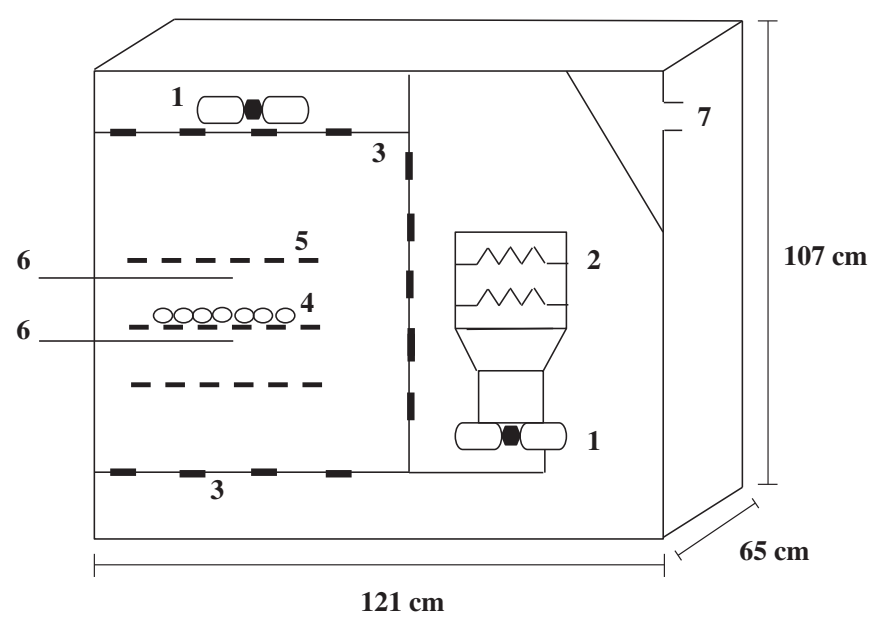

Fig. 1. A schematic view of the hot air convection oven (not to scale) (Memmert, Germany): fan (1); heater (2); perforated plate (3); chestnut fruits (4); shelf (5); temperature sensors (6); point of velocity measurement (7); and air exhaust (8). 
where $W, W_{0}$ and $W_{e}$ represent the instantaneous, initial and equilibrium dry basis water contents ( $\mathrm{kg}$ water $/ \mathrm{kg}$ dry basis), respectively. $W_{e}$ was determined as the asymptotic value of the function fit of the experimental points at the final stage of drying. Several empirical and semi-theoretical models were tested to fit the moisture ratio/ time (Table 1). These models have been used for mathematical modeling of drying with several vegetable products (Karathanos, 1999; Karathanos \& Belessiotis, 1999; Özdemir \& Devres, 1999; Phoungchandang \& Woods, 2000; Xanthopoulos, Yanniotis, \& Lambrinos, 2010).

Model parameters were determined by the SPSS $®$ software (Version No. 20.0), and the suitability of the fit was evaluated by the following parameters:

SSE $=\sum_{i=1}^{n}\left(y_{\text {exp }, i}-y_{\text {model }, i}\right)^{2}$

$S S T=\sum_{i=1}^{n}\left(y_{\text {exp }}-y_{\text {average }}\right)^{2}$

$R^{2}=1-\frac{S S E}{S S T}$

$R^{2} \operatorname{adj}=1-\frac{S S E \times(n-1)}{S S T \times v}$ where $v=n-m$

$R M S E=\sqrt{\frac{S S E}{v}}$

where $y_{\text {exp,i }}$ and $y_{\text {model, } i}$ are the experimental and predicted values for the $i$ observation, respectively, $n$ is the number of observations and $m$ is the number of parameters in each model (Togrul \& Pehlivan, 2003; Yaldýz \& Ertekýn, 2001).

\subsection{Estimation of the apparent diffusivities}

In the present work no constant rate period was observed, the dehydration rate being limited by moisture diffusion from inside to the surface layer of the chestnuts. Thus, the Fick's second law equation for nonsteady-state diffusion was applied. After verifying that chestnuts could be approximated to spheres and after finding the best method to estimate their sphere equivalent radius, the following mathematical solution was used, associating moisture content and drying time, and considering uniform initial moisture distribution and surface moisture in equilibrium with the air conditions (Crank, 1975).

$\frac{W-W_{e}}{W_{0}-W_{e}}=\frac{6}{\pi^{2}} \sum_{i=1}^{\infty} \frac{1}{n^{2}} \exp \left(-D_{a p p} \frac{n^{2} \pi^{2}}{R^{2}} t\right)$, where $D_{a p p}$ is the apparent diffusivity, $R$ is equal to the SER and $t$ is time (expressed in hours) (Özdemir \& Devres, 1999).

For high drying times, all other terms of the series may be regarded as negligible compared to the first and after taking the natural logarithm of each side of Eq. (12), the equation assumes the following form:

$\ln \left(\frac{W-W_{e}}{W_{o}-W_{e}}\right)=\ln \frac{6}{\pi^{2}}-D_{a p p} \frac{\pi^{2}}{R^{2}} t$

After representing $\ln \left(\frac{W-W_{e}}{W_{0}-W_{e}}\right)$ versus $t$, a linear relationship was obtained and its equation determined. The apparent diffusivity was calculated by the following equation:

$D_{\text {app }}=\frac{\text { slope } \times R^{2}}{\pi^{2}}$

To check shrinkage influence in apparent diffusivity, the variation of the radius was taken into account in Eq. (12) during drying by considering the measurements of the radius in function of time:

$\frac{W-W_{e}}{W_{0}-W_{e}}=\frac{6}{\pi^{2}} \sum_{i=1}^{\infty} \frac{1}{n^{2}} \exp \left(-D_{a p p} \frac{n^{2} \pi^{2}}{R(t)^{2}} t\right)$

Thus, the apparent diffusivity was deduced from the slope of the straight-line $\ln \left(\frac{W-W_{e}}{W_{o}-W_{e}}\right)$ versus $\frac{t}{R(t)^{2}}$. The apparent diffusivities determined with correction for shrinkage and without correction for shrinkage were then compared and the shrinkage influence on diffusivity was illustrated.

\subsection{Microscopic analysis of chestnut shells}

The outer and inner shells were examined by bright-field light microscopy. For each variety, seven chestnuts were selected randomly and the hard outer shell and inner shell were carefully removed with a blade. Semi-thin sections of the outer and inner shells were then cut by hand into random longitudinal or transversal sections, mounted in water and observed on a light microscope (Leitz laborlux 12) equipped with a camera (Nikon SMZ-U). The thickness of the outer shell and the cells' length and the width of the outer and inner shells were measured.

\section{Results and discussion}

3.1. Influence of drying on chestnut dimensions, volumetric shrinkage and color

After measuring the axial dimensions of the fresh chestnut fruits (before drying), differences were found between varieties, the Longal nuts being generally smaller (lower $W, t, A R$ and $G R$ values) than the

Table 1

Single-layer drying models used in the present work.

\begin{tabular}{|c|c|c|}
\hline Model name & Equation & Reference \\
\hline Lewis & $M R=\exp (-k \cdot t)$ & $\begin{array}{l}\text { Bruce (1985), Özdemir and Devres (1999), Phoungchandang and Woods (2000) and Xanthopoulos } \\
\text { et al. (2010) }\end{array}$ \\
\hline Page & $M R=\exp \left(-k \cdot t^{n}\right)$ & $\begin{array}{l}\text { Bruce (1985) Karathanos and Belessiotis (1999) Özdemir and Devres (1999) and Xanthopoulos et al. } \\
\text { (2010) }\end{array}$ \\
\hline Modified Page & $M R=\exp \left(-(k \cdot t)^{n}\right)$ & White, Bridges, Loewer, and Ross (1981) and Özdemir and Devres (1999) \\
\hline Henderson and Pabis & $M R=a \exp (-k \cdot t)$ & $\begin{array}{l}\text { Henderson and Pabis (1961), Karathanos (1999), Özdemir and Devres (1999) and Xanthopoulos } \\
\text { et al. (2010) }\end{array}$ \\
\hline Logarithmic & $M R=a \exp (-k \cdot t)+c$ & Yaldýz and Ertekýn (2001) and Xanthopoulos et al. (2010) \\
\hline Two-term & $M R=a \exp \left(-k_{0} \cdot t\right)+b \exp \left(-k_{1} \cdot t\right)$ & Henderson (1974), Özdemir and Devres (1999) and Xanthopoulos et al. (2010) \\
\hline Two-term exponential & $M R=a \exp (-k \cdot t)+(1-a) \exp (-k \cdot a \cdot t)$ & Henderson (1974) \\
\hline Wang and Singh & $M R=1+a \cdot t+b \cdot t^{2}$ & Wang and Singh (1978), Özdemir and Devres (1999) and Xanthopoulos et al. (2010) \\
\hline Diffusion Approach & $M R=a \exp (-k \cdot t)+(1-a) \exp (-k \cdot b \cdot t)$ & Kassem (1998) \\
\hline $\begin{array}{l}\text { Modified Henderson and } \\
\text { Pabis }\end{array}$ & $\begin{array}{l}M R=a \exp (-k \cdot t)+b \exp (- \\
g \cdot t)+c \exp (-h \cdot t)\end{array}$ & Karathanos (1999) and Xanthopoulos et al. (2010) \\
\hline Thompson & $t=a \ln M R+b(\ln M R)^{2}$ & Thompson, Peart, and Foster (1968) and Özdemir and Devres (1999) \\
\hline
\end{tabular}


Table 2

Chestnut fruit dimensions before and after drying.

\begin{tabular}{|c|c|c|c|c|c|c|}
\hline \multicolumn{7}{|c|}{ A) Nuts with outer shell } \\
\hline \multicolumn{4}{|l|}{ Judia } & \multicolumn{3}{|l|}{ Longal } \\
\hline \multirow[t]{2}{*}{ Dimensions } & \multirow{2}{*}{$\frac{\text { Before drying }}{\text { Fruit with outer shell }}$} & \multicolumn{2}{|l|}{ After drying } & \multirow{2}{*}{$\frac{\text { Before drying }}{\text { Fruit with outer shell }}$} & \multicolumn{2}{|l|}{ After drying } \\
\hline & & Fruit with outer shell & Fruit without outer shell & & Fruit with outer shell & Fruit without outer shell \\
\hline$W(\mathrm{~mm})$ & $36.46 \pm 2.58 \mathrm{a}$ & $36.10 \pm 2.51 \mathrm{a}$ & $31.92 \pm 2.69 b$ & $29.09 \pm 2.47 \mathrm{a}$ & $28.38 \pm 2.47 a$ & $25.54 \pm 2.47 \mathrm{~b}$ \\
\hline$L(\mathrm{~mm})$ & $33.65 \pm 1.93 a$ & $32.92 \pm 1.88 \mathrm{~b}$ & $29.09 \pm 2.53 c$ & $34.75 \pm 2.17 \mathrm{a}$ & $33.64 \pm 2.12 b$ & $30.09 \pm 2.66 c$ \\
\hline$t(\mathrm{~mm})$ & $21.65 \pm 2.45 a$ & $21.12 \pm 2.04 a$ & $17.73 \pm 2.22 b$ & $19.99 \pm 2.52 \mathrm{a}$ & $19.48 \pm 2.44 a$ & $17.07 \pm 2.45 b$ \\
\hline$A R(\mathrm{~mm})$ & $15.29 \pm 0.67 a$ & $15.02 \pm 0.65 a$ & $13.12 \pm 0.76 b$ & $13.97 \pm 0.87 a$ & $13.58 \pm 0.86 b$ & $12.12 \pm 0.90 c$ \\
\hline$G R(\mathrm{~mm})$ & $14.88 \pm 0.70 \mathrm{a}$ & $14.61 \pm 0.67 a$ & $12.68 \pm 0.79 b$ & $13.59 \pm 0.91 a$ & $13.22 \pm 0.89 b$ & $11.75 \pm 0.92 c$ \\
\hline \multicolumn{7}{|c|}{ B) Nuts with inner shell } \\
\hline \multicolumn{4}{|l|}{ Judia } & & \multicolumn{2}{|l|}{ Longal } \\
\hline Dimensions & \multicolumn{2}{|c|}{ Before drying } & After drying & & Before drying & After drying \\
\hline$W(\mathrm{~mm})$ & \multicolumn{2}{|c|}{$34.56 \pm 2.05 a$} & $32.23 \pm 2.31 b$ & \multicolumn{2}{|r|}{$26.45 \pm 1.84 a$} & $25.17 \pm 1.84 \mathrm{~b}$ \\
\hline$L(\mathrm{~mm})$ & \multicolumn{2}{|c|}{$31.26 \pm 2.49 a$} & $29.16 \pm 2.55 b$ & \multicolumn{2}{|r|}{$30.98 \pm 1.83 a$} & $29.55 \pm 2.17 b$ \\
\hline$t(\mathrm{~mm})$ & \multicolumn{2}{|c|}{$20.47 \pm 3.09 a$} & $19.26 \pm 2.72 b$ & \multicolumn{2}{|r|}{$14.78 \pm 1.85 a$} & $14.07 \pm 1.64 b$ \\
\hline$A R(\mathrm{~mm})$ & \multicolumn{2}{|c|}{$14.38 \pm 0.92 \mathrm{a}$} & $13.44 \pm 0.89 b$ & \multicolumn{2}{|r|}{$12.04 \pm 0.59 \mathrm{a}$} & $11.47 \pm 0.57 b$ \\
\hline$G R(\mathrm{~mm})$ & \multicolumn{2}{|c|}{$13.99 \pm 1.02 a$} & $13.09 \pm 0.95 b$ & \multicolumn{2}{|r|}{$11.45 \pm 0.62 \mathrm{a}$} & $10.91 \pm 0.57 b$ \\
\hline
\end{tabular}

$W$-width; $L$-length; $t$-thickness; $A R$-arithmetic mean radius; $G R$-geometric mean radius. In each row and for each variety, different letters mean significant differences $(\mathrm{P}<0.05)$.

Judia ones (Table 2). The higher values for the Judia variety are in accordance with a recognized increased size of this variety. Regarding sphericity, this parameter varied between 0.70 and 0.79 for Longal and 0.79 and 0.87 for Judia, respectively, also suggesting differences on fruit shape.

When observing the axial dimensions $(W, L, t)$ and the arithmetic and geometric radii of chestnuts dried with the outer shell (pericarp) (Table 2A), no differences were found before and after drying the fruits of Judia variety, with the exception of length $(L)$. On the opposite, significant differences were observed in almost all parameters for the Longal variety, with the exception of width $(W)$ and thickness $(t)$, suggesting that this chestnut variety underwent a higher shape variation during drying than the Judia variety. Additionally, after peeling the outer shell of the dried nuts (Table $2 \mathrm{~A}$ ) a 3 to $4 \mathrm{~mm}$ size reduction was observed in comparison with the shelled fresh fruits, for both varieties.

Regarding drying of chestnuts with inner shell (Table 2B), all the previous discussed dimensional parameters were significantly different $(p<0.05)$ before and after drying for both varieties. However, and in opposition to the expected, the differences observed before and after drying (around 1 to $2 \mathrm{~mm}$ ) were lower than those determined on fruits dried with the outer shell (Table 2A). These results suggested that the occurrence of volumetric shrinkage might not be very significant during drying.

In order to verify if this hypothesis was correct, the Bulk Shrinkage Coefficient was determined. Firstly it was necessary to find an expeditious and no time-consuming method of determining chestnut volume in order to apply Eq. (5). Thus, in a chestnut sub-sample, the volume of each fruit was determined by the displacement method (Mohsenin, 1970), the radius of the sphere of the same volume as the fruit being determined. Then, this radius (SER) was compared with the arithmetic $(A R)$ and geometric $(G R)$ mean radii determined for the same chestnuts and good linear relationships were obtained for both varieties (Fig. 2). Slopes very close to 1 and ordinates at the origin close to zero were determined, indicating that chestnut volume can be easily predicted through the calculation of the arithmetic or geometric mean radius. Taking into account the linear correlation coefficients $(R)$, the geometric mean radius provided a better estimate of the SER for the Judia variety, whereas the arithmetic mean radius gave better results for the Longal

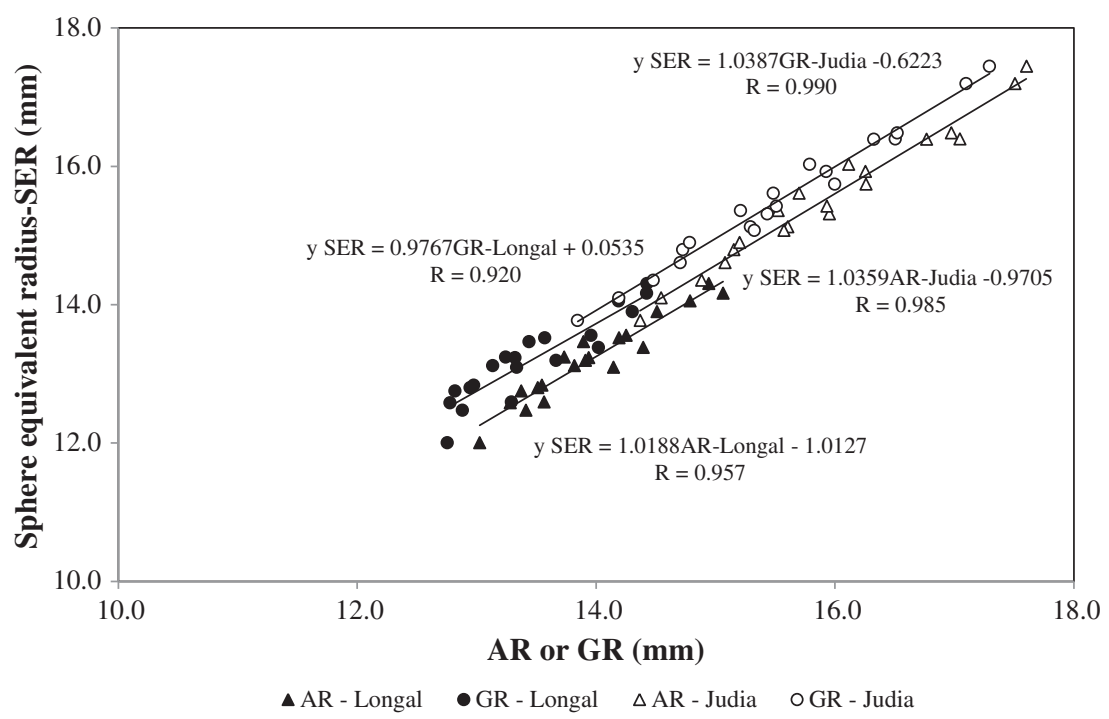

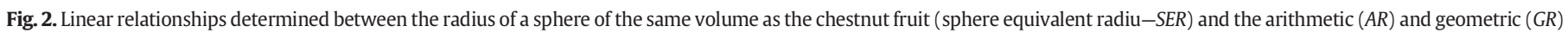
radii. 
variety. Thus, through the measurement of the axial dimensions of the fruits of both varieties, the Bulk Shrinkage Coefficients were evaluated along the drying process. It should be mentioned that as the volumetric shrinkage becomes more significant, this coefficient tends to 1 . On the contrary, if the volumetric shrinkage is negligible, the Bulk Shrinkage Coefficient will be close to zero. During the drying of chestnuts with outer shell, no increase in this parameter was observed for both varieties and the mean values were close to zero: $0.050 \pm 0.022$ for Judia and $0.078 \pm 0.031$ for Longal, indicating that the volumetric shrinkage was negligible (less than $10 \%$ ). When the chestnut fruits were dried only with the inner shell, slightly higher coefficients were obtained. However, the mean values remained low, $0.175 \pm 0.065$ for Judia and $0.132 \pm 0.046$ for Longal, without any tendency to increase during drying. These results indicated that the volumetric shrinkage was not high (less than 24\%), being comparatively lower than other foodstuffs (fruits and vegetables) that can reach final shrinkage coefficients from 70 to 90\% (Mayor \& Sereno, 2004).

When fruits were dried with outer shell (Fig. 3 A and B), lower values of both $\mathrm{L}^{*}$ and $\mathrm{b}^{*}$ were obtained for the Longal variety, indicating the fruits had lower brightness and yellowness than the Judia variety. During drying, a decrease in the fruits' interior brightness $\left(\mathrm{L}^{*}\right)$ (after cutting through the middle) was observed over time for both varieties. In terms of yellowing ( $b^{*}$ parameter), the chestnuts without inner shell of the Judia variety showed a more uniform increase than the Longal variety at the early stages of drying, indicating a slight yellowing of the Judia chestnuts. Regarding the fruits' interior (after cutting), there was no yellowing of the fruits' interior along the dehydration process at $50{ }^{\circ} \mathrm{C}$ in both varieties.
During the drying of chestnuts with inner shell (Fig. 3C and D), a slight decrease in the fruit's brightness was detected for both varieties. In terms of peeled dried fruits' yellowing, the $b^{*}$ parameter increased in the early stages of drying on both varieties but only on the outer surface.

\subsection{Shell's influence on chestnuts' drying kinetics}

The drying curves of the two chestnut varieties, with and without outer shell, are shown in Fig. 4. All curves were almost identical, with a very fast moisture removal at the beginning of the drying process, independently of the shell, slowing down as the drying proceeded. Both varieties required around $40-45$ and $35-40 \mathrm{~h}$ to reach the values of $M R$ near 0.2 when dried with (Fig. 4 A and B) and without (Fig. 4 C and D) outer shells, respectively. The minor reduction in drying time observed after removal of the outer shell indicated that this shell did not exert a high resistance to water loss. This fact explains the significant weight losses reported by chestnut producers during fruit storage, our results being in line with those reported by Moreira et al. (2005), who had confirmed that the inner pellicle exerted a higher resistance than the outer shell.

Curve fitting computations were carried on the drying models described in Table 1, the results being presented in Fig. 4. The model parameters and those statistics used to evaluate model suitability are presented in Tables 3 and 4. In general, it was found that most of the models described the experimental data efficiently. From the statistical parameters calculated it was also observed that the quality of the fits was good for both chestnut varieties subjected to drying with outer
A

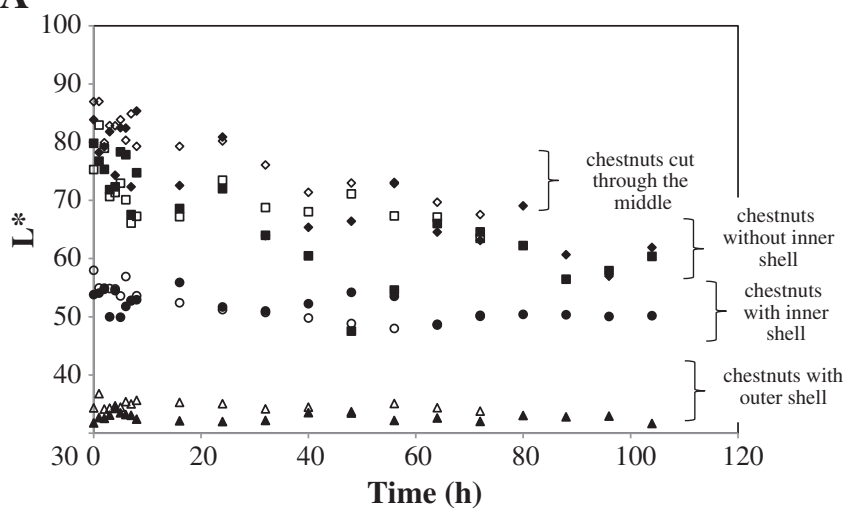

C

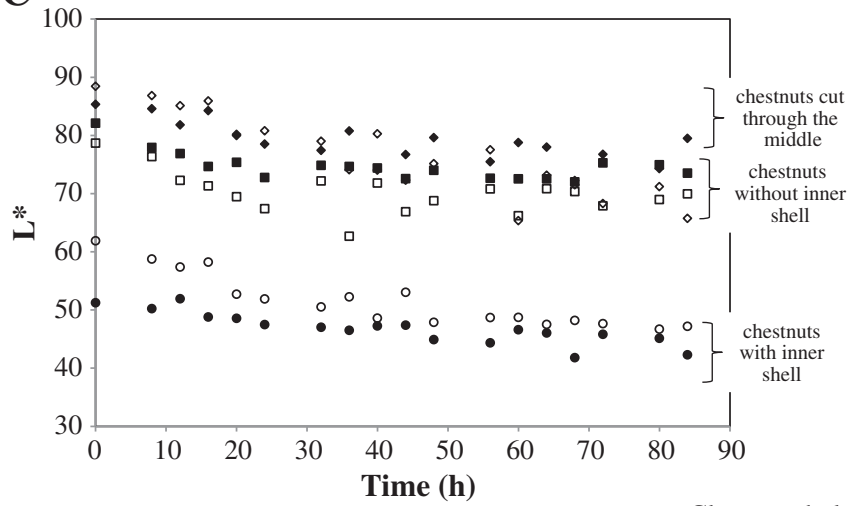

B

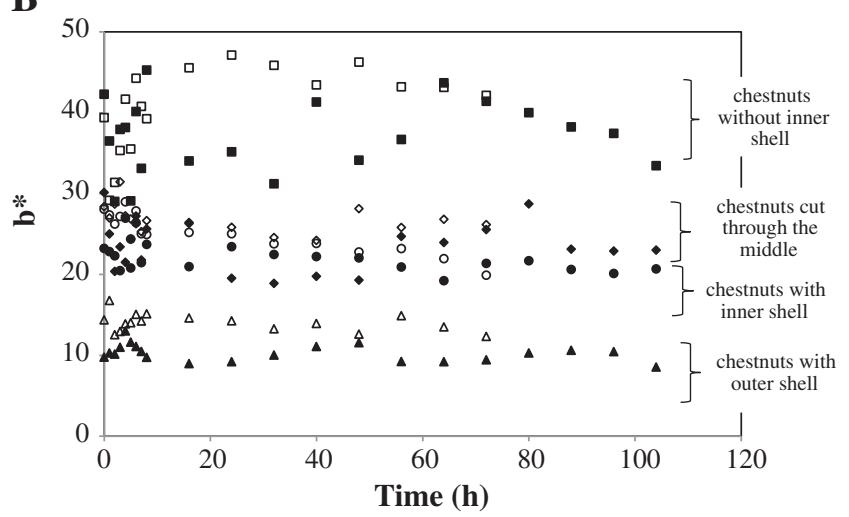

D

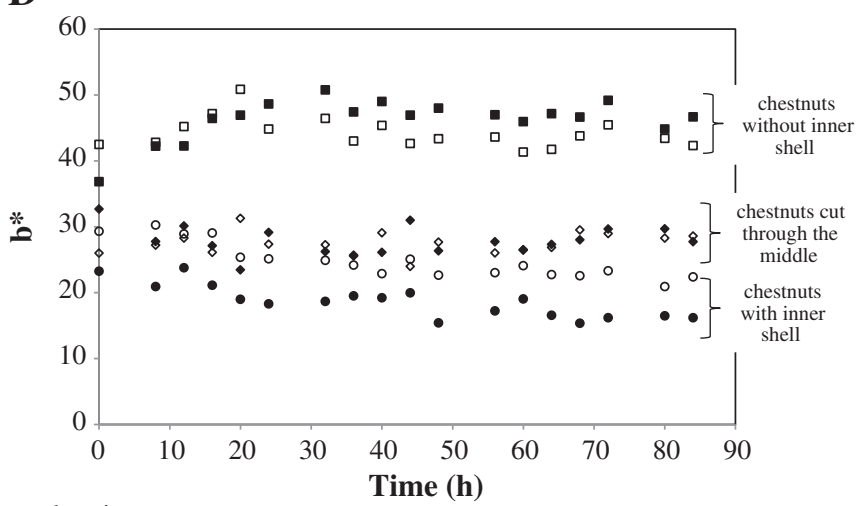

Close symbols-Longal variety

Open symbols - Judia variety

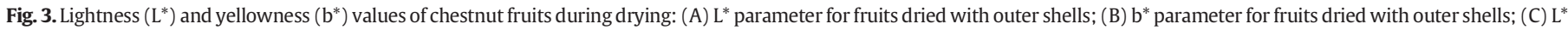

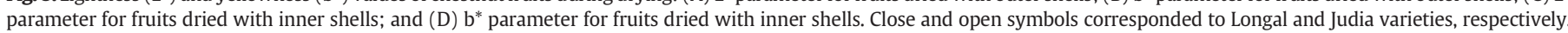
Triangles-chestnuts with outer shell; circles-chestnuts with inner shell; squares-chestnuts without inner shell; rhombus-chestnuts cut through the middle. 

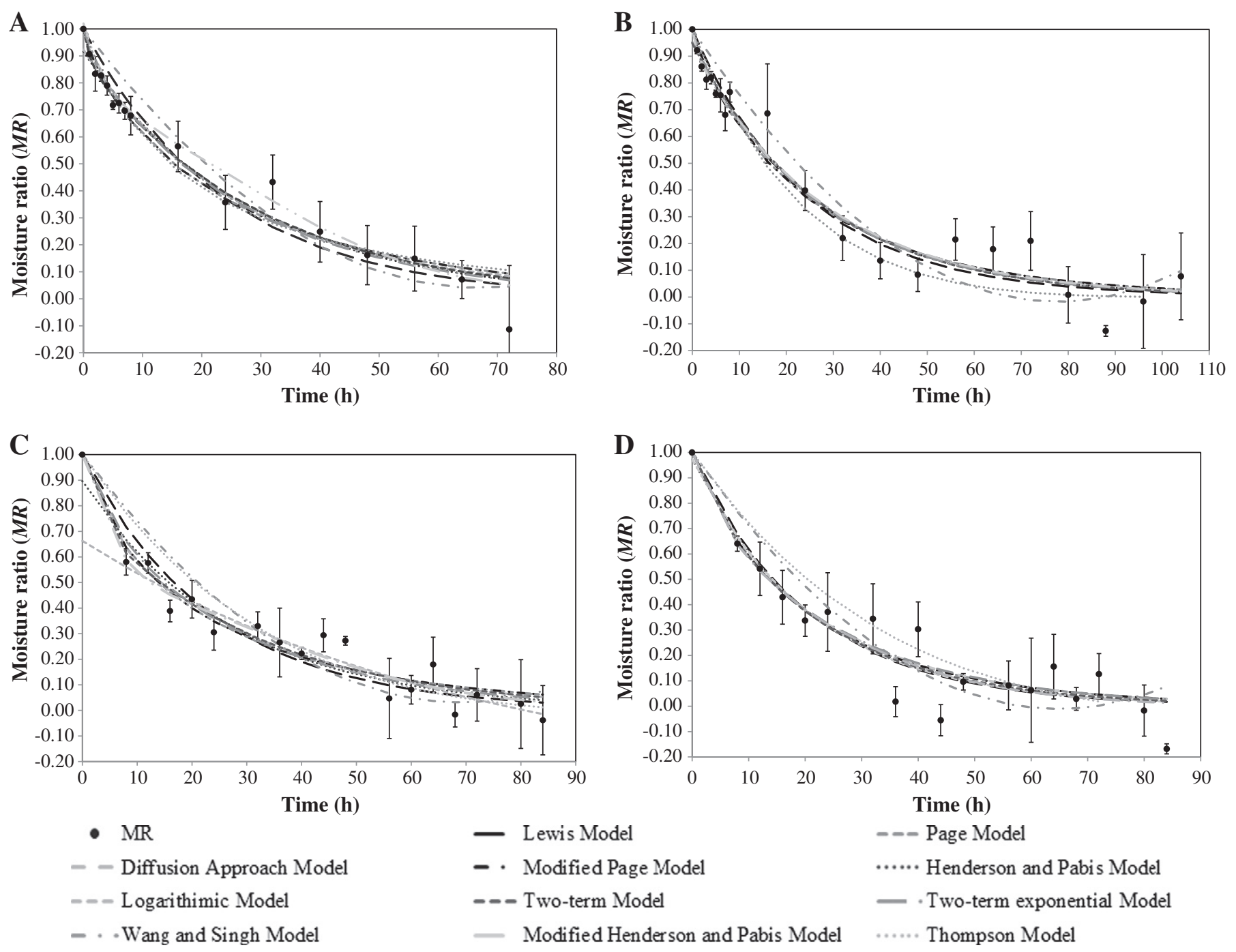

Fig. 4. Drying curves of (A) Judia variety with outer shell; (B) Longal variety with outer shell; (C) Judia variety with inner shell; and (D) Longal variety with inner shell.

shell (Table 3 ) and inner shell (Table 4 ), with $R$-squares in the range of 0.778 and 0.986 and Adjusted $R$-squares in the range of 0.764 to 0.984 . As some values were near 1.0, these models described well the experimental data. SSE and RMSE also presented low values (close to zero, as desired), varying between 0.0255 and 0.314 and 0.0412 and 0.140 , respectively. The results showed that the most appropriate models in describing drying rates of chestnuts of Judia variety with outer shell were the Page and Modified Page models (both with the highest Adjusted $R$ square and the lowest SSE and RMSE values), whereas for chestnuts with only inner shell the Page model was the one that yielded the best fit (the highest Adjusted $R$-square, 0.926 , and the lowest RMSE), closely followed by the Two-term exponential and Logarithmic models (Adjusted $R$ squares equal to 0.923 and 0.922 , respectively). Regarding the Longal variety, the most appropriate model in describing drying rates of chestnuts with outer shell was the Two-term exponential model (with the highest Adjusted $R$-square, 0.946 , and the lowest SSE and RMSE), closely followed by the Page, Modified Page, and Henderson and Pabis models, all of them with an Adjusted $R$-square equal to 0.945, SSE of 0.14 and $R M S E<0.087$. When drying chestnuts of the Longal variety with only the inner shell, the Modified Page model was the one that yielded the best fit (Adjusted $R$-square $=0.872$ ), followed by the Two-term exponential (Adjusted $R$-square $=0.866$ ), both models with the lowest SSE and RMSE values. Our results are in line with Guiné and Fernandes (2006) and Velić et al. (2010) who also obtained a good agreement between the drying data after applying the Two-term exponential and Page Models, respectively. Our results also showed that the use of models with a high number of parameters did not bring any advantage. Moreover, when considering all model parameters (Tables 3 and 4) and in particular those of the Page and Modified Page models that gave good results for both varieties, the model parameters were similar when drying chestnuts with outer shell and inner shell for both chestnut varieties.

The apparent diffusivities for chestnuts dried with outer and inner shells of the Longal and Judia varieties are listed in Table 5. According to the results obtained, there was not a remarkable difference between the apparent diffusivities determined without taking into account shrinkage and when shrinkage correction is considered. Thus, apparent diffusivity of chestnuts is not significantly affected when shrinkage is not taken into account in the drying data of chestnuts. Moreover, the results also showed that the presence of outer and inner shells of nuts did not affect the values of apparent diffusivity, showing again that the outer shell caused a small resistance to mass transfer.

Nevertheless, an unexpected fact was observed. Despite being of reduced significance, the fruits dried with outer shell presented slightly higher apparent diffusivities than those dried with inner shell for both varieties. This fact may be attributed to the case hardening effect (Xanthopoulos et al., 2010) that may occur in products having high sugar content, being more significant when fruits without outer shell 
Table 3

Model parameters and statistics used to evaluate the suitability of the models for chestnuts drying (fruits with outer shell) of Longal and Judia varieties.

\begin{tabular}{|c|c|c|c|c|c|c|}
\hline Model & Model parameters & R-square & $\begin{array}{l}\text { Adjusted } \\
R \text {-square }\end{array}$ & SSE & RMSE & Variety \\
\hline \multirow[t]{2}{*}{ Lewis } & $k=0.0415$ & 0.943 & 0.943 & 0.101 & 0.0794 & Judia \\
\hline & $k=0.0406$ & 0.943 & 0.943 & 0.154 & 0.0878 & Longal \\
\hline \multirow[t]{2}{*}{ Page } & $\begin{array}{l}k=0.0800 \\
n=0.793\end{array}$ & 0.986 & 0.984 & 0.0255 & 0.0412 & Judia \\
\hline & $\begin{array}{l}k=0.0588 \\
n=0.884\end{array}$ & 0.947 & 0.945 & 0.143 & 0.0867 & Longal \\
\hline \multirow[t]{2}{*}{ Diffusion approach } & $\begin{array}{l}a=0.111 \\
k=0.935 \\
b=0.0365\end{array}$ & 0.984 & 0.982 & 0.0281 & 0.0448 & Judia \\
\hline & $\begin{array}{l}a=0.0641 \\
k=1.68 \\
b=0.0216\end{array}$ & 0.949 & 0.943 & 0.139 & 0.0879 & Longal \\
\hline \multirow[t]{2}{*}{ Modified Page } & $\begin{array}{l}k=0.0414 \\
n=0.793\end{array}$ & 0.986 & 0.984 & 0.0255 & 0.0412 & Judia \\
\hline & $\begin{array}{l}k=0.0405 \\
n=0.884\end{array}$ & 0.947 & 0.945 & 0.143 & 0.0867 & Longal \\
\hline \multirow[t]{2}{*}{ Henderson and Pabis } & $\begin{array}{l}a=0.916 \\
k=0.0356\end{array}$ & 0.981 & 0.980 & 0.0327 & 0.0467 & Judia \\
\hline & $\begin{array}{l}a=0.952 \\
k=0.0372\end{array}$ & 0.948 & 0.945 & 0.142 & 0.0864 & Longal \\
\hline \multirow[t]{2}{*}{ Logarithmic } & $\begin{array}{l}a=0.895 \\
k=0.0383 \\
c=0.0282\end{array}$ & 0.980 & 0.977 & 0.0360 & 0.0507 & Judia \\
\hline & $\begin{array}{l}a=0.952 \\
k=0.0371 \\
c=-6.60 \times 10^{-6}\end{array}$ & 0.947 & 0.942 & 0.143 & 0.0892 & Longal \\
\hline \multirow[t]{2}{*}{ Two-term } & $\begin{array}{l}a=0.111 \\
k_{0}=0.939 \\
b=0.889 \\
k_{1}=0.0341\end{array}$ & 0.980 & 0.975 & 0.0351 & 0.0520 & Judia \\
\hline & $\begin{array}{l}a=0.983 \\
k_{0}=0.0379 \\
b=-0.0351 \\
k_{1}=0.0977\end{array}$ & 0.947 & 0.938 & 0.144 & 0.0921 & Longal \\
\hline \multirow[t]{2}{*}{ Two-term exponential } & $\begin{array}{l}a=0.101 \\
k=0.354\end{array}$ & 0.981 & 0.980 & 0.0329 & 0.0468 & Judia \\
\hline & $\begin{array}{l}a=0.0595 \\
k=0.620\end{array}$ & 0.949 & 0.946 & 0.139 & 0.0856 & Longal \\
\hline \multirow[t]{2}{*}{ Wang and Singh } & $\begin{array}{l}a=-0.0287 \\
b=0.000215\end{array}$ & 0.896 & 0.889 & 0.184 & 0.111 & Judia \\
\hline & $\begin{array}{l}a=-0.0262 \\
b=0.000168\end{array}$ & 0.904 & 0.899 & 0.262 & 0.117 & Longal \\
\hline \multirow[t]{2}{*}{ Mod. Henderson and Pabis } & $\begin{array}{l}a=-198 \\
k=0.0847 \\
b=93.7 \\
g=0.0913 \\
c=106 \\
h=0.0787\end{array}$ & 0.979 & 0.970 & 0.0367 & 0.0578 & Judia \\
\hline & $\begin{array}{l}a=0.0676 \\
k=1.34 \\
b=0.272 \\
g=0.0358 \\
c=0.662 \\
h=0.0357\end{array}$ & 0.950 & 0.934 & 0.136 & 0.0951 & Longal \\
\hline \multirow[t]{2}{*}{ Thompson } & $\begin{array}{l}a=-16.0 \\
b=7.13\end{array}$ & 0.948 & 0.945 & 0.0905 & 0.0777 & Judia \\
\hline & $\begin{array}{l}a=-23.1 \\
b=-1.34\end{array}$ & 0.936 & 0.932 & 0.165 & 0.0959 & Longal \\
\hline
\end{tabular}

are subjected to heat. Furthermore, only slight differences between varieties were observed.

\subsection{Microscopic analysis of chestnut shells}

When observing the outer shells by microscopy, slight differences were observed between varieties (Fig. 5). In particular, the cross sections (Fig. 5A and B) presented some differences on their thicknesses. The outer shell of the Judia variety had higher thickness (556 $\pm 43 \mu \mathrm{m})$ than the Longal (328 $\pm 66 \mu \mathrm{m}$ ), suggesting a small loss of water of the Judia variety and explaining the slight lower values of $D_{a p p}$ obtained when the fruits of this variety were dried with outer shell. Nevertheless, the fruits of the Judia variety are generally bigger than those of the Longal variety, originating a higher surface area and explaining the identical drying behavior obtained for both varieties.

Regarding the cell size of the outer shell (Fig. 5C and D), some differences were again observed. The width of the Longal variety cells (35 $\pm 7 \mu \mathrm{m}$ ) was slight higher than that of the Judia $(24 \pm 5 \mu \mathrm{m})$, whereas no differences in height were observed (Longal: $15 \pm 3 \mu \mathrm{m}$ versus Judia: $14 \pm 3 \mu \mathrm{m}$ ). Concerning the cell format, they were more regular in the Longal variety (Fig. 5C) than in the Judia (Fig. 5D). 
Table 4

Model parameters and statistics used to evaluate the suitability of the models for chestnut drying (fruits with inner shell) of Longal and Judia varieties.

\begin{tabular}{|c|c|c|c|c|c|c|}
\hline Model & Model parameters & R-square & Adjusted $R$-square & SSE & RMSE & Variety \\
\hline \multirow[t]{2}{*}{ Lewis } & $k=0.0415$ & 0.891 & 0.891 & 0.124 & 0.0856 & Judia \\
\hline & $k=0.0484$ & 0.846 & 0.846 & 0.218 & 0.113 & Longal \\
\hline \multirow[t]{4}{*}{ Page } & $k=0.0905$ & 0.930 & 0.926 & 0.0802 & 0.0708 & Judia \\
\hline & $n=0.773$ & & & & & \\
\hline & $k=0.0669$ & 0.871 & 0.862 & 0.184 & 0.101 & Longal \\
\hline & $n=0.896$ & & & & & \\
\hline \multirow[t]{6}{*}{ Diffusion approach } & $a=0.213$ & 0.919 & 0.908 & 0.0927 & 0.0786 & Judia \\
\hline & $k=0.277$ & & & & & \\
\hline & $b=0.116$ & & & & & \\
\hline & $a=0.128$ & 0.962 & 0.844 & 0.195 & 0.114 & Longal \\
\hline & $k=0.297$ & & & & & \\
\hline & $b=0.140$ & & & & & \\
\hline \multirow[t]{4}{*}{ Modified Page } & $k=0.0447$ & 0.918 & 0.913 & 0.0938 & 0.0766 & Judia \\
\hline & $n=0.774$ & & & & & \\
\hline & $k=0.0489$ & 0.871 & 0.872 & 0.184 & 0.107 & Longal \\
\hline & $n=0.896$ & & & & & \\
\hline \multirow[t]{4}{*}{ Henderson and Pabis } & $a=0.896$ & 0.900 & 0.894 & 0.114 & 0.0845 & Judia \\
\hline & $k=0.0370$ & & & & & \\
\hline & $a=0.973$ & 0.854 & 0.845 & 0.207 & 0.114 & Longal \\
\hline & $k=0.0470$ & & & & & \\
\hline \multirow[t]{6}{*}{ Logarithmic } & $a=0.994$ & 0.931 & 0.922 & 0.0788 & 0.0725 & Judia \\
\hline & $k=0.0136$ & & & & & \\
\hline & $c=-0.331$ & & & & & \\
\hline & $a=0.974$ & 0.854 & 0.835 & 0.206 & 0.117 & Longal \\
\hline & $k=0.0473$ & & & & & \\
\hline & $c=-3.62 \times 10^{-5}$ & & & & & \\
\hline \multirow[t]{8}{*}{ Two-term } & $a=0.204$ & 0.920 & 0.903 & 0.0915 & 0.0808 & Judia \\
\hline & $k_{0}=2.71$ & & & & & \\
\hline & $b=0.796$ & & & & & \\
\hline & $k_{1}=0.0325$ & & & & & \\
\hline & $a=0.920$ & 0.867 & 0.839 & 0.188 & 0.116 & Longal \\
\hline & $k_{0}=0.0449$ & & & & & \\
\hline & $b=-0.0797$ & & & & & \\
\hline & $k_{1}=91.8$ & & & & & \\
\hline \multirow[t]{4}{*}{ Two-term exponential } & $a=0.187$ & 0.918 & 0.923 & 0.0942 & 0.0767 & Judia \\
\hline & $k=0.184$ & & & & & \\
\hline & $a=0.134$ & 0.874 & 0.866 & 0.178 & 0.106 & Longal \\
\hline & $k=0.305$ & & & & & \\
\hline \multirow[t]{4}{*}{ Wang and Singh } & $a=-0.0280$ & 0.789 & 0.776 & 0.242 & 0.123 & Judia \\
\hline & $b=0.000202$ & & & & & \\
\hline & $a=-0.0312$ & 0.778 & 0.764 & 0.314 & 0.140 & Longal \\
\hline & $b=0.000240$ & & & & & \\
\hline \multirow[t]{12}{*}{ Mod. Henderson and Pabis } & $a=-276$ & 0.939 & 0.914 & 0.0698 & 0.0763 & Judia \\
\hline & $k=0.0766$ & & & & & \\
\hline & $b=138$ & & & & & \\
\hline & $g=0.0721$ & & & & & \\
\hline & $c=139$ & & & & & \\
\hline & $h=0.0812$ & & & & & \\
\hline & $a=34.4$ & 0.875 & 0.823 & 0.177 & 0.122 & Longal \\
\hline & $k=0.0765$ & & & & & \\
\hline & $b=18.9$ & & & & & \\
\hline & $g=0.0934$ & & & & & \\
\hline & $c=-52.4$ & & & & & \\
\hline & $h=0.0828$ & & & & & \\
\hline \multirow[t]{4}{*}{ Thompson } & $a=-31.6$ & 0.864 & 0.856 & 0.156 & 0.0986 & Judia \\
\hline & $b=-2.86$ & & & & & \\
\hline & $a=-31.8$ & 0.788 & 0.773 & 0.245 & 0.132 & Longal \\
\hline & $b=-3.46$ & & & & & \\
\hline
\end{tabular}

Cells of inner shell were also observed microscopically in this work, but no differences between varieties were detected (data not shown).

Table 5

Apparent diffusivity of chestnuts $\left(\mathrm{m}^{2} / \mathrm{h}\right)$ of Longal and Judia varieties dried with outer and inner shells: comparison of non-corrected and corrected values for shrinkage.

\begin{tabular}{lll}
\hline & $\begin{array}{l}D_{a p p}\left(\mathrm{~m}^{2} / \mathrm{h}\right) \\
\text { non-corrected for shrinkage }\end{array}$ & $\begin{array}{l}D_{\text {app }}\left(\mathrm{m}^{2} / \mathrm{h}\right) \\
\text { corrected for shrinkage }\end{array}$ \\
\hline Longal with outer shell & $9.54 \times 10^{-7}-1.24 \times 10^{-6}$ & $9.24 \times 10^{-7}-1.20 \times 10^{-6}$ \\
Longal with inner shell & $2.72 \times 10^{-7}-6.99 \times 10^{-7}$ & $1.92 \times 10^{-7}-6.81 \times 10^{-7}$ \\
Judia with outer shell & $6.58 \times 10^{-7}-8.26 \times 10^{-7}$ & $6.35 \times 10^{-7}-8.03 \times 10^{-7}$ \\
Judia with inner shell & $3.87 \times 10^{-7}-7.96 \times 10^{-7}$ & $3.15 \times 10^{-7}-7.77 \times 10^{-7}$ \\
\hline
\end{tabular}

\section{Conclusions}

After performing this work, it was demonstrated that the ovendrying behavior of chestnuts of two varieties of NE of Portugal, Longal and Judia, was similar, despite the microscopic differences detected in thickness and cell size of the outer shell. It was also verified that the outer shell exerted a small influence on the drying kinetics of both varieties. This point is very important to guarantee the success of chestnut oven-drying industrial process because it shows that it is unnecessary to take off the outer shell, leading to a more economical and nontime-consuming process. After determining the suitability of several drying models, it was concluded that the use of models with a high number of parameters did not bring any advantage, the Page (outer 

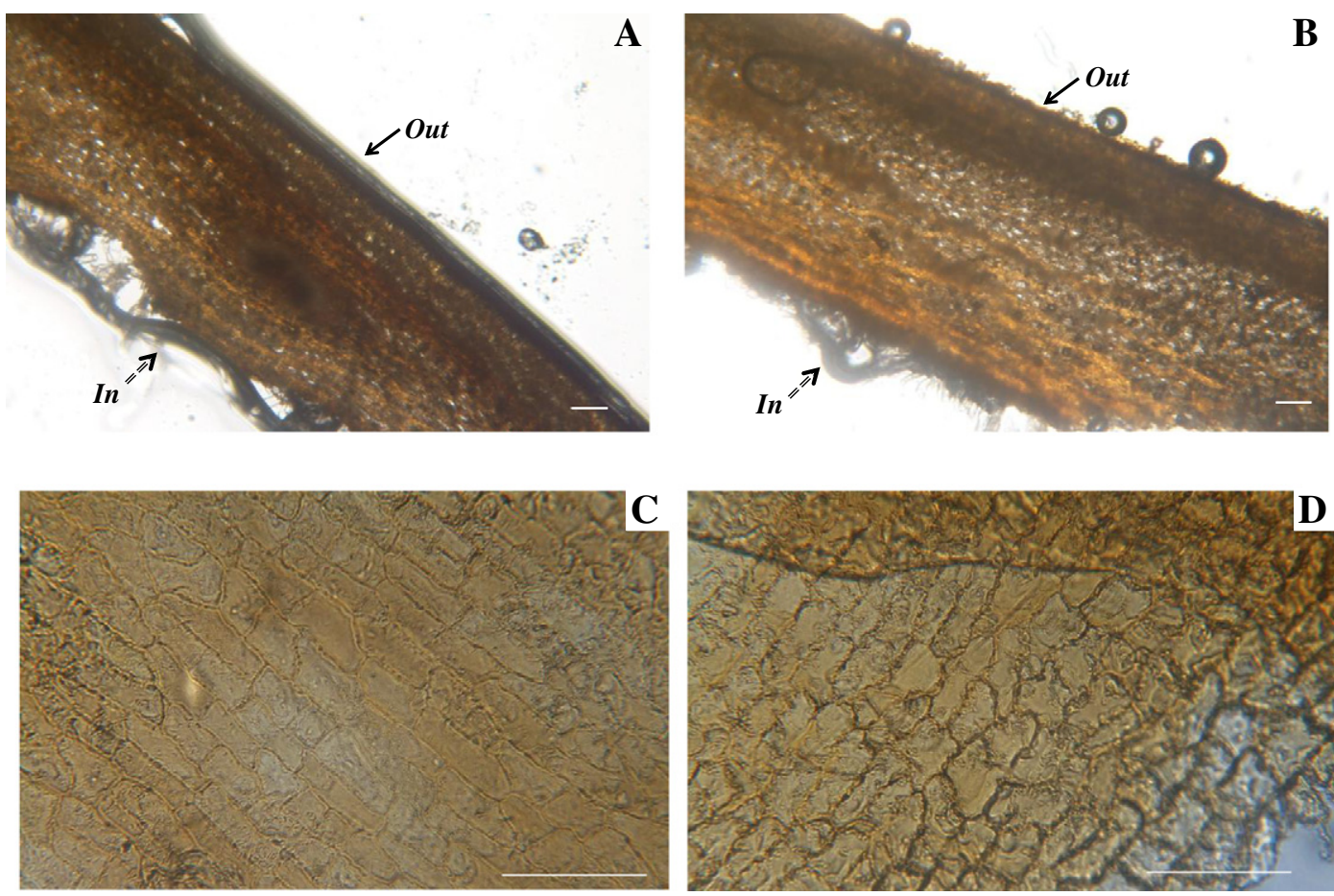

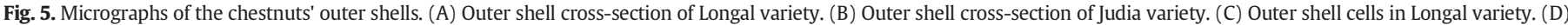
Outer shell cells in Judia variety. Scale bars: $50 \mu \mathrm{m}$.

and inner shell) and Modified Page models (outer shell) being suitable for the Judia variety and the Two-Term Exponential (outer shell) and the Modified Page models (inner shell) for the Longal variety. Concerning the fruit color, a slight decrease in fruit brightness and an increase on fruit yellowness were detected along drying for both varieties. Regarding volumetric shrinkage, this was less than 10 and 24\% when fruits were dried with and without outer shell, respectively, and so chestnut fruits of the Longal and Judia varieties shrink less compared to other fruits and vegetables. Our results showed that both varieties seem to be adequate to be used industrially to produce chestnut based products, demonstrating similar drying behaviors.

\section{Acknowledgments}

Teresa Delgado acknowledges the Fundação para a Ciência e Tecnologia (FCT) for the financial support through the PhD grantSFRH/BD/82285/2011, CIMO through the Project PEst-OE/AGR/UI0690/ 2011 and REQUIMTE through the Project PEst-C/EQB/LA0006/2011.

\section{References}

Attanasio, G., Cinquanta, L., Albanese, D., \& Di Matteo, M. (2004). Effects of drying temperatures on physico-chemical properties of dried and rehydrated chestnuts (Castanea sativa). Food Chemistry, $88,583-590$

Bruce, D.M. (1985). Exposed-layer barley drying, three models fitted to new data up to $150{ }^{\circ} \mathrm{C}$. Journal of Agricultural Engineering Research, 32, 337-347.

Cecchini, M., Contini, M., Massantini, R., Monarca, D., \& Moscetti, R. (2011). Effects of controlled atmospheres and low temperature on storability of chestnuts manually and mechanically harvested. Postharvest Biology and Technology, 61, 131-136.

Chandrasekara, N., \& Shahidi, F. (2011). Effect of roasting on phenolic content and antioxidant activities of whole cashew nuts, kernels, and testa. Journal of Agricultural and Food Chemistry, 59, 5006-5014.

Chenlo, F., Moreira, R., \& Torres, M.D. (2007). Rheological properties of chestnuts processed by osmotic dehydration and convective drying. Food Science and Technology International, 13, 369-374.

Crank, J. (1975). The mathematics of diffusion. Oxford, UK: Claredon Press, 89-103.

Dissa, A. O., Desmorieux, H., Savadogo, P. W., Segda, B. G., \& Koulidiati, J. (2010). Shrinkage, porosity and density behaviour during convective drying of spirulina. Journal of Food Engineering, 97, 410-418.

Guiné, R. P. F., \& Fernandes, R. M. C. (2006). Analysis of the drying kinetics of chestnuts. Journal of Food Engineering, 76, 460-467.
Henderson, S. M. (1974). Progress in developing the thin layer drying equation. Transactions of the American Society of Agricultural Engineers, 17, 1167-1172.

Henderson, S. M., \& Pabis, S. (1961). Grain drying theory I: Temperature effect on drying coefficient. Journal of Agricultural Engineering Research, 6, 169-174.

Karathanos, V. T. (1999). Determination of water content of dried fruits by drying kinetics. Journal of Food Engineering, 39, 337-344.

Karathanos, V. T., \& Belessiotis, V. G. (1999). Application of a thin-layer equation to drying data of fresh and semi-dried fruits. Journal of Agricultural Engineering Research, 74 355-361.

Kassem, A. S. (1998). Comparative studies on thin layer drying models for wheat. 13th International Congress on Agricultural Engineering, Morocco, 2nd to 6th February, Vol. 6, .

Kilic, A. (2009). Low temperature and high velocity (LTHV) application in drying: Characteristics and effects on the fish quality. Journal of Food Engineering, 91, 173-182.

Koyuncu, T., Serdar, U., \& Tosun, I. (2004). Drying characteristics and energy requirement for dehydration of chestnuts (Castanea sativa Mill.). Journal of Food Engineering, 62, 165-168.

Mayor, L., \& Sereno, A.M. (2004). Modelling shrinkage during convective drying of food materials: A review. Journal of Food Engineering, 61, 373-386.

Mohsenin, N. N. (1970). Physical properties of plant and animal materials. New York, USA: Gordon and Breach Science Publishers, 86-88.

Moreira, R., Chenlo, F., Chaguri, L., \& Oliveira, H. (2007). Drying of chestnuts (Castanea sativa Mill.) after osmotic dehydration with sucrose and glucose solutions. Drying Technology, 25, 1837-1845.

Moreira, R., Chenlo, F., Chaguri, L., \& Vázquez, G. (2005). Mathematical modelling of the drying kinetics of chestnut (Castanea sativa Mill.), influence of the natural shells. Food and Byproducts Processing, 83, 306-314.

Moreira, R., Chenlo, F., Torres, M.D., \& Vázquez, G. (2007). Effect of stirring in the osmotic dehydration of chestnut using glycerol solutions. LWT-Food Science and Technology, 40, 1507-1514.

Özdemir, M., \& Devres, Y. O. (1999). The thin layer drying characteristics of hazelnuts during roasting. Journal of Food Engineering, 42, 225-233.

Phoungchandang, S., \& Woods, J. L. (2000). Moisture diffusion and desorption isotherms for banana. Journal of Food Science, 65, 651-657.

Pinnavaia, G. G., Pizzirani, S., \& Papotto, E. G. (1995). Study of the production feasibility of a extruded chestnut flour product. Industrie Alimentari, 34, 977-984.

Rodrigues, P., Venâncio, A., \& Lima, N. (2012). Mycobiota and mycotoxins of almonds and chestnuts with special reference to aflatoxins. Food Research International, 48 76-90.

Shahidi, F., \& Chandrasekara, N. (2011). High temperature short time roasting increase phenolics content and antioxidant activity of cashew nuts. Abstracts of papers of the American Chemical Society, 241 (49-AGFD)

Tang, J., Ikediala, J. N., Wang, S., Hansen, J.D., \& Cavalieri, R. P. (2000). Hightemperature-short-time thermal quarantine methods. Postharvest Biology and Technology, 21, 129-145.

Thompson, T. L., Peart, R. M., \& Foster, G. H. (1968). Mathematical simulation of corn drying-A new model. Transactions of the American Society of Agricultural Engineers, $11,582-586$. 
Togrul, I. T., \& Pehlivan, D. (2003). Modelling of drying kinetics of single apricot. Journal of Food Engineering, 58, 23-32.

Velić, D., Ačkar, D., Mujić, I., Šubarić, I., Bilić, M., \& Jokić, S. (2010). Influence of drying temperature on drying kinetics and physico-chemical properties of two chestnut varieties (Castanea sativa Mill.). Acta Horticulturae, 866, 635-645.

Wang, C. Y., \& Singh, R. P. (1978). A single layer drying equation for rough rice. American Society of Agricultural Engineers (Paper No. 3001)
White, G. M., Bridges, T. C., Loewer, O. J., \& Ross, I. J. (1981). Thin layer drying model for soybeans. Transactions of the American Society of Agricultural Engineers, 24, $1643-1649$.

Xanthopoulos, G., Yanniotis, S., \& Lambrinos, Gr (2010). Study of the drying behaviour in peeled and unpeeled whole figs. Journal of Food Engineering, 97, 419-424.

Yaldýz, O., \& Ertekýn, C. (2001). Thin layer solar drying of some vegetables. Drying Technology, 19, 583-597. 